\title{
Heterotopic en bloc tracheobronchial transplantation with direct revascularization in pigs
}

\author{
Amarilio Macedo, MD, $\mathrm{PhD}^{\mathrm{a}}$ \\ Elie Fadel, $\mathrm{MD}, \mathrm{PhD}^{\mathrm{a}}$ \\ Guy-Michel Mazmanian, $\mathrm{MD}^{\mathrm{b}}$ \\ Vincent de Montpréville, $\mathrm{MD}^{\mathrm{b}}$ \\ Michèle German-Fattal, $\mathrm{PhD}^{\mathrm{C}}$ \\ Sacha Mussot, MD \\ Alain Chapelier, MD, PhD \\ Philippe G. Dartevelle, $\mathrm{MD}^{\mathrm{a}}$
}

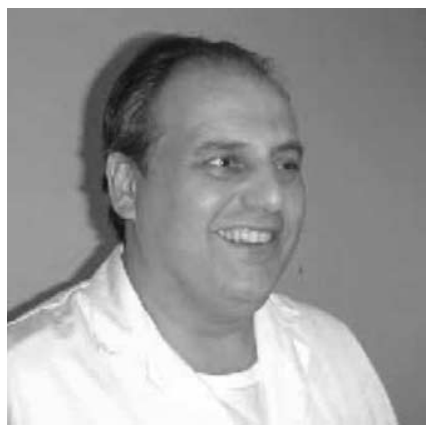

Dr Macedo

From the Department of Thoracic and Vascular Surgery and Heart-Lung Transplantation, ${ }^{a}$ the Experimental Surgery Laboratory, $^{\mathrm{b}}$ and CNRS-ESA 8078 Laboratory, ${ }^{\mathrm{c}}$ Hôpital Marie-Lannelongue, Paris-Sud University, Le Plessis-Robinson, France.

Supported by grants from the Fondation de l'Avenir, France, and by CAPES-MEC, Brasília, Brazil

Received for publication Sept 1, 2003; revisions received Jan 7, 2004; accepted for publication Jan 27, 2004.

Address for reprints: Amarilio Macedo, MD, PhD, Department of Thoracic Surgery and Lung Transplantation, Hospital de Clínicas de Porto Alegre, Federal University of Rio Grande do Sul, 2350, Ramiro Barcellos St, Room 2050, 2nd Floor, 90035-003, Porto Alegre, Brazil (E-mail: amariliomacedo@terra.com.br).

J Thorac Cardiovasc Surg 2004;127: 1593-601

$0022-5223 / \$ 30.00$

Copyright (C) 2004 by The American Association for Thoracic Surgery

doi:10.1016/j.jtcvs.2004.01.039
Objective: This article describes the application of a novel aortic tube technique for directly revascularized tracheobronchial transplantation with dual blood supply in pigs.

Methods: Eleven adult Large White pigs underwent heterotopic tracheal transplantation with a dual revascularization technique (inferior thyroid artery and bronchial artery). Seven tracheobronchial grafts were perfused ex vivo, and hemodynamic data were collected.

Results: At the last evaluation, 6 pigs had normally epithelialized mucus-producing allografts with correct morphologic conformation and cartilage viability. The histopathologic examination revealed homogeneous tissue regardless of biopsy site (trachea, carina, or bronchi), demonstrating the efficacy of the revascularization procedure. Four animals had early ischemic necrosis develop, 2 from acute rejection and 2 from technical mishap. One additional pig had acute rejection starting on the 14th postoperative day. The $\mathrm{CD} 4^{+} / \mathrm{CD} 8^{+}$ratio was maintained close to or above 0.8 in the subgroup with rejection and below 0.6 in the animals that were correctly immunosuppressed. Pressure-flow curves in 7 ex vivo tracheobronchial grafts showed a nonsignificant difference $(P<.12)$ in vascular resistance between the bronchial artery territory (lower resistance) and the inferior thyroid artery territory.

Conclusions: For the first time, a transplantation technique encompassing the entire trachea, carina, and stem bronchi has been made possible. By means of the dual inferior thyroid and bronchial artery axis, we were able to obtain a structurally healthy and functional graft to replace the main airway.

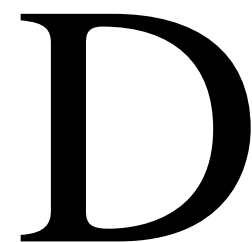

irectly revascularized tracheal and tracheobronchial transplantation may be useful in patients in whom native airway tissue is not amenable for primary reconstruction. ${ }^{1-4}$ Most importantly, in a time of great achievements in thoracic transplantation it is important to think about the trachea as an organ to be transplanted, rather than as a simple conduit to be replaced.

Recent efforts with cryopreserved tracheal allografts with indirect blood supply, ${ }^{5}$ with autografts, ${ }^{6}$ and with tissue-engineered cartilage ${ }^{7}$ present a major shortcoming: the compromised viability of long grafts $(>4-5 \mathrm{~cm})$. The time required for omentopexy wrapping revascularization (major ischemia in the first 3-7 posttransplantation days) $)^{8,9}$ and correct allograft re-epithelialization (about 50 days in 5- to 7-ring allografts $)^{10}$ invariably leads to malacia or necrosis in long allografts. 
Neville and colleagues ${ }^{11}$ have stated that tracheal reconstruction should not be attempted in human beings unless a method for immediate revascularization of allografts can be devised. Our group has previously demonstrated the feasibility of heterotopic pig allografts measuring as much as $63 \%(9.7 \mathrm{~cm})$ of the tracheal length. ${ }^{12}$ Because the trachea has a proximal vascular pedicle that is hard to set apart from other structures and is not manageable by microsurgical anastomosis, we developed two strategies for revascularization: (1) interposition of donor right subclavian artery into recipient cervical arterial system, allowing supply of blood to the graft by branches of the inferior thyroid artery, and (2) adequate venous drainage through the superior vena cava effluent to avoid venous infarction and subsequent arterial thrombosis.

On the basis of those initial studies, and taking into consideration the rich anastomotic network running along the tracheal axis, ${ }^{13}$ we set out to develop a method to quickly revascularize the entire trachea, including the carina and stem bronchi. The question we asked was whether the inferior thyroid axis was sufficient to vascularize the aforementioned portions. The need to add the bronchial artery to supply the lower trachea, carina, and stem bronchi seemed inescapable, because in preliminary experiments with a single blood supply these areas showed ischemic-necrotic changes. The same type of finding has been observed in some patients submitted to lung transplantation without bronchial artery revascularization. ${ }^{14}$

With the aim of achieving a dual blood supply (inferior thyroid and bronchial arteries), we devised an original technique anastomosing the aortic tube to the brachiocephalic artery. This article describes the application of this new technique to tracheobronchial transplantation.

\section{Material and Methods}

Thirty young male Large White pigs were purchased from Etablissements Cegav (St Marc d'Egrenne, France). The animals weighed 15 to $25 \mathrm{~kg}$ on arrival and were housed and handled in compliance with the "Guide for the Care and Use of Laboratory Animals" (http://www.nap.edu/catalog/5140.html). Tracheobronchial transplantation was performed in 16 animals. In addition, 7 animals were assigned to the angiographic and anatomic pilot study, and 7 were assigned to the study of the hemodynamic graft ex vivo.

In a first series of 5 transplanted pigs, the inferior thyroid artery was used as the sole vascular pedicle, as previously described elsewhere. ${ }^{12}$ However, this pedicle proved insufficient to revascularize the inferior portion of the trachea, the carina, and the stem bronchi. Therefore a dual revascularization technique, with the inferior thyroid artery and the bronchial artery, was developed and tested in 11 animals. The results presented here refer only to the 11 animals in which dual revascularization (aortic tube technique) was used.

\section{Experimental Protocol}

The animals were premedicated intramuscularly with ketamine hydrochloride $(60 \mathrm{mg} / \mathrm{kg})$ and anesthetized intravenously with sodium pentobarbital $(12.5 \mathrm{mg} / \mathrm{kg})$. After orotracheal intubation, anesthesia was maintained with inhaled halothane ( $0.5 \%$ to $1 \%)$, and the lungs were ventilated (Siemens, Solna, Sweden) with an equal mixture of air and oxygen at a tidal volume of $250 \mathrm{~mL}$ and a rate of 20 breaths/min. Peripheral vascular access was accomplished by placing a 20-gauge angiocatheter into an ear vein. The adequacy of ventilation and oxygenation was assessed by arterial blood gas analysis and pulse oximetry. Continuous monitoring of cardiac electrical activity was also performed.

\section{En Bloc Cervicomediastinal Harvesting}

The harvesting procedure comprised 15 steps. (1) With animals in the supine position, a midline cervicothoracic incision with total sternotomy was performed, exposing the cervicothoracic junction. (2) The platysma muscle, cervical thymus glands with the underlying omohyoid, and sternothyroid muscles were excised bilaterally. (3) The inferior cervical lymph nodes were removed, and the triangular retrosternal ligament was sectioned. (4) The mediastinal thymus gland was excised. (5) The right and left azygos veins were ligated at their confluence into the superior vena cava. (6) The internal thoracic, vertebral, and first intercostal arteries and veins were dissected and ligated. (7) The subclavian and external and internal jugular veins were isolated at their origins and encircled. (8) The distal portion of the subclavian artery and the common carotid artery were isolated and encircled. (9) After intravenous administration of heparin $(3 \mathrm{mg} / \mathrm{kg})$, the superior and inferior venae cavae were ligated, and the heart was fibrillated with an electric shock. (10) All previously isolated cervical vessels were then ligated and divided between ligatures. (11) The superior vena cava and ascending aorta were transected, and all blood was aspirated. (12) The inferior vena cava, descending aorta, and the esophagus were sectioned close to the diaphragm. (13) Sharp dissection and cauterization were used to achieve the posterior extrapleural plane. (14) Cervical stage began with an "out-in" side division of muscular attachments and clipping of the arteries and venules emerging from the posterior cervical muscles. Finally, (15) cervicomediastinal (heart-lung block) exenteration was made after dividing the proximal esophagus and the cricothyroid membrane.

\section{Graft Conditioning}

The heart and both lungs were removed, with care taken to prevent the tiny network of paratracheal and peribronchial vessels from being injured. Thus the paratracheal and subcarinal lymph nodes and the thyroid gland were kept in place. After a longitudinal esophagotomy, we stripped out the mucosa, leaving the muscular layer in close contact with the membranous trachea.

To construct the aortic tube model (Figure 1), the left anterolateral descending aorta was longitudinally opened at the level of the aortic arch, and the bronchial artery was identified. ${ }^{15}$ Fabiani solution $\left(4^{\circ} \mathrm{C}\right)$ was retrogradely perfused through the distal right subclavian artery and through the aortic tube until a good return through the vena cava was observed. The distal subclavian artery was tied. The allograft was maintained in cold saline solution $\left(4^{\circ} \mathrm{C}\right)$ before transplantation into the recipient animal. 


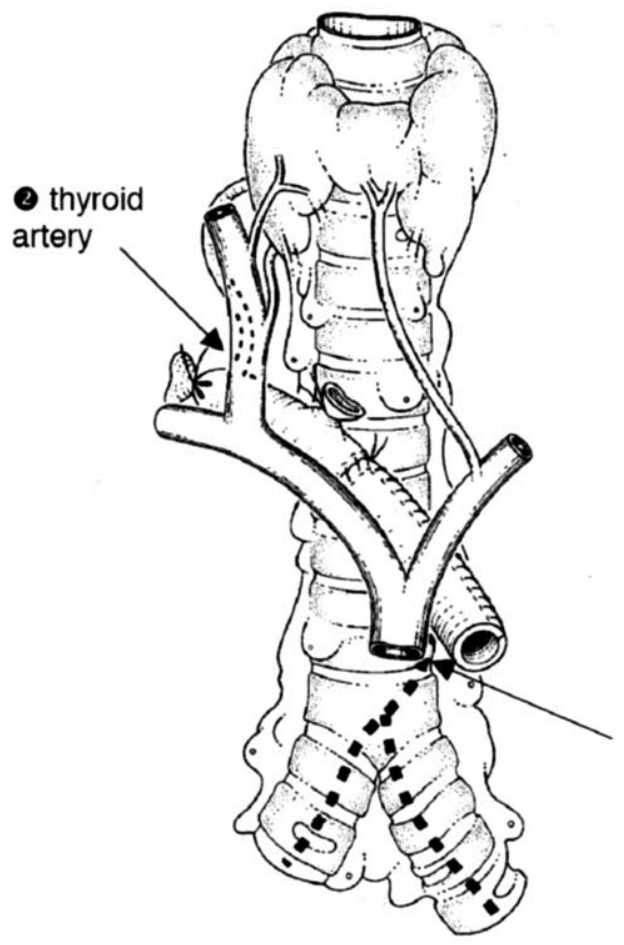

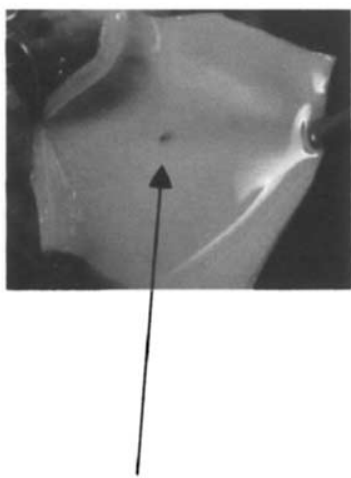

bronchial artery

Figure 1. Tracheobronchial transplantation with dual blood supply technique. Aortic width was reduced by $1.5-\mathrm{cm}$ longitudinal resection (compatible with brachiocephalic artery width). Afterward, cross-section of aorta was performed $2.5 \mathrm{~cm}$ proximally and $2.5 \mathrm{~cm}$ distally in relation to bronchial artery (1). Double running 6-0 polypropylene suture was used to close patch longitudinally. End-to-end 6-0 polypropylene continuous suture was used to anastomose aortic tube to brachiocephalic artery at its origin. 2, Thyroid artery; 3, superior vena cava.

\section{Fabiani Solution}

The Fabiani solution was made by adding $1626 \mathrm{~g} \mathrm{MgCl}_{2} 6 \mathrm{H}_{2} \mathrm{O}$, $0.596 \mathrm{~g} \mathrm{KCl}, 0.136 \mathrm{~g}$ procaine chlorohydrate, and $5000 \mathrm{IU}$ heparin to $\mathrm{CP} 1 \mathrm{~A}\left(8.59 \mathrm{~g} \mathrm{NaCl}, 0.298 \mathrm{~g} \mathrm{KCl}, 0.294 \mathrm{~g} \mathrm{CaCl}_{2}, 0.345 \mathrm{~g}\right.$ trometalol, $\mathrm{HCl}$ as needed to achieve $\mathrm{pH} 8$, and sterile water to achieve a volume of $1000 \mathrm{~mL}$; Laboratoires Chaix et Du Marais, Paris, France).

\section{Allograft Transplantation}

Cervicotomy was performed, and the brachiocephalic junction was exposed. The brachiocephalic veins and the superior vena cava were encircled with tourniquets and left untied. The left carotid artery was exposed, and silicone loops were placed proximally and distally in relation to the arteriotomy site. After surgical closure of the loops to obstruct blood flow, an end-to-side anastomosis (6-0 Prolene suture; Ethicon, Inc, Somerville, NJ) was made between the aortic tube and the left carotid artery. The silicone loops were then loosened, allowing recirculation. Graft hemostasis was checked and perfected. By tightening the tourniquets, a wide phlebotomy area was established at the confluence of the recipient's vena cava and right brachiocephalic trunk. An end-to-side anastomosis (7-0 Prolene suture) was performed between these vessels and the donor's superior vena cava. The graft was positioned transversely with its posterior wall facing the front. The donor's tracheal and bronchial orifices were anastomosed to the skin with a 2-0 polyglactin suture (Vicryl, Ethicon). A large tubular drain was inserted before closing the muscular and skin planes (2-0 Vicryl).

\section{Postoperative Course and Immune Suppression}

The daily regimen was as follows: intramuscular cefotaxime (1 g) and gentamicin ( $80 \mathrm{mg}$ ), subcutaneous nadroparin (2050 IU), oral acetylsalicylic acid (100 mg). Fiberoptic examinations and biopsies were performed in each of the following sites on postoperative days 2, 7, 14, and 21: midtrachea, carina, right main bronchus, and left main bronchus. The animals were killed (barbiturate overdose) at 3 weeks or in case of extensive graft necrosis.

Immune suppression was induced with intramuscular methylprednisolone (240 $\mathrm{mg}$ just before graft reperfusion and $40 \mathrm{mg}$ on postoperative days 1 and 3), oral azathioprine $(2.5 \mathrm{mg} / \mathrm{kg})$, and intramuscular cyclosporine (Sandimmune; INN: ciclosporin). The daily dose of cyclosporine was 5 to $10 \mathrm{mg} / \mathrm{kg}$, starting the morning after the operation. Our goal was to maintain cyclosporine levels between 100 and $300 \mathrm{ng} / \mathrm{mL}$ in total blood. Cyclosporinemia was checked before administration of a new dose.

\section{Histologic Studies}

Tracheobronchial lesions (epithelial dedifferentiation, squamous metaplasia, ulceration or necrosis) were categorized according to the following criteria: (1) ischemia (in the absence of inflammation), (2) acute rejection (when associated with lymphocytic infil- 


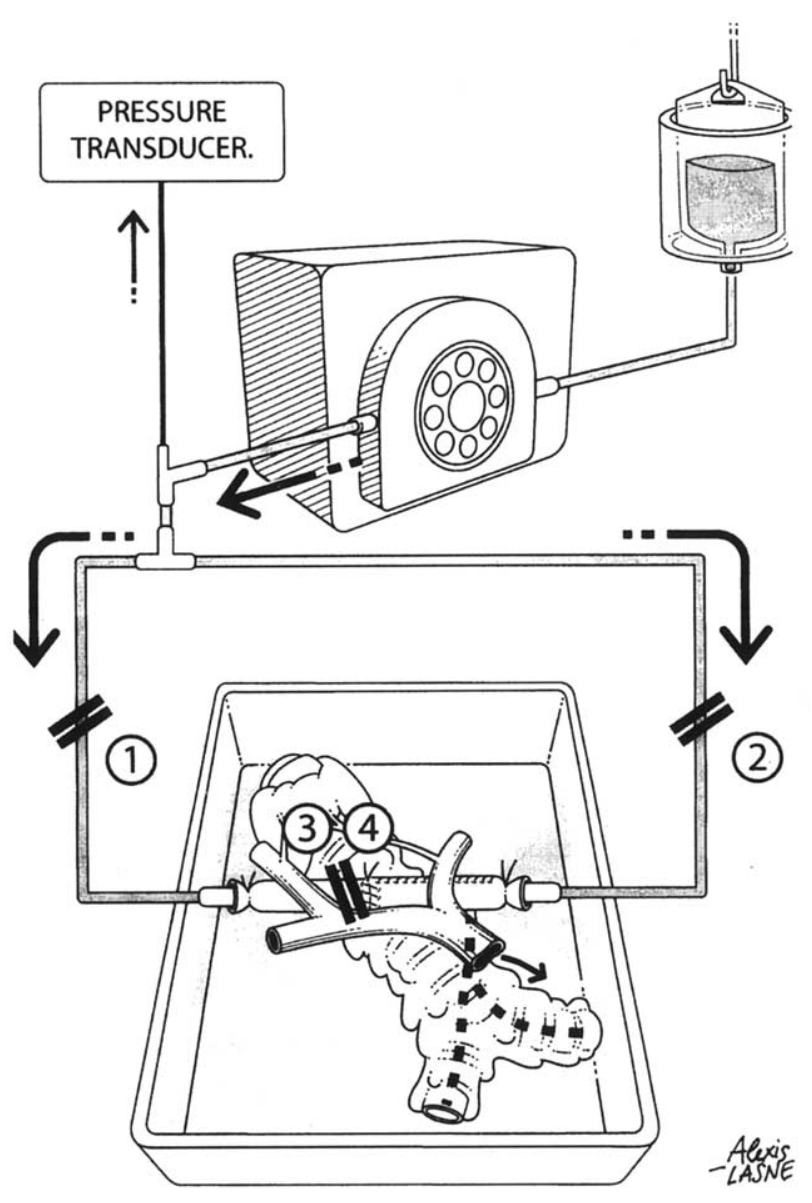

Figure 2. Ex vivo tracheobronchial allograft. Alternate perfusion and clamping yielded the following hemodynamic conditions: aortic tube cannulation with bronchial and inferior thyroid vascular bed perfusion (1), distal subclavian artery cannulation with bronchial and inferior thyroid vascular bed perfusion (2), distal subclavian artery cannulation with thyroid vascular bed perfusion only (3), and aortic tube cannulation with only bronchial vascular bed perfusion (4).

trate in the chorion), and (3) primary or secondary infection (in the presence of polynuclear cell infiltrate into the chorion with leukocytic debris and/or germs). All grafts were submitted to postmortem macroscopic and histologic examinations.

\section{Flow Cytometric Phenotype Analysis}

Immunocytometric analysis of peripheral blood lymphocytes was performed in 6 pigs on days $0,3,7$, and 21 to assess T-cell subsets with triple staining with labeled antipig CD3e-CD4a and CD8a monoclonal antibodies (BD Pharmigen, San Diego, Calif).

\section{Ex Vivo Pressure-Flow Relationship in Isolated}

\section{Tracheobronchial Grafts}

Tracheobronchial allografts were alternatively cannulated and perfused. The perfusion flow rate was increased in a stepwise fashion from 0 to $10 \mathrm{~mL} / \mathrm{min}$ with homologous normothermic blood under

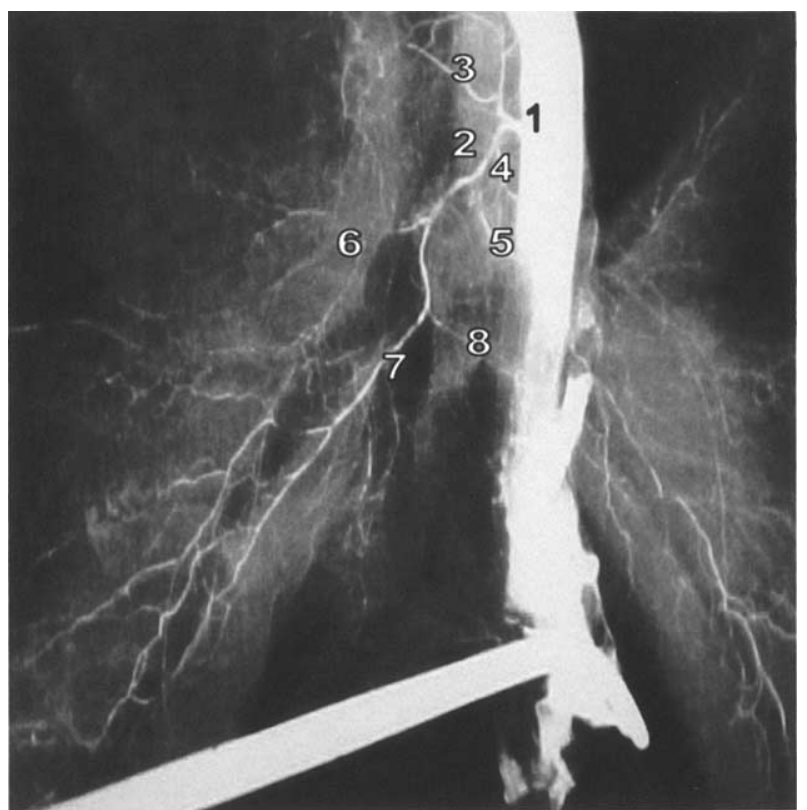

Figure 3. Ex vivo bronchial arteriography. Descending aorta is crossclamped at level of isthmus. Lead tetroxide (Minium) is injected retrogradely in descending aorta. After takeoff from aorta, bronchial (bronchoesophageal ${ }^{16}$ ) artery (1) divides into carinal (2) and second branch toward inferior part of trachea and esophagus (3). Small tributary vessel takes off from carinal artery toward left cranial lobe (4) and forms lateral branch (5) toward left main bronchus. Positioned directly over carina, carinal (6) artery further divides into lateral (7) and medial (8) branches toward right main bronchus and into left medial branch toward left main bronchus.

four experimental conditions (Figure 2). Perfusion pressure was measured with a Gould transducer (P23ID; Gould Inc, Oxnard, Calif) connected to the perfusion line. Flow rate was measured with a transit-time flowmeter probe (model T106; Transonic Systems Inc, Ithaca, NY) connected in series with the perfusion line. The recorded perfusion pressures were plotted against flow rate readings with a commercial software package (Kaleidagraph; Synergy Software, Reading, $\mathrm{Pa}$ ).

\section{Statistical Analysis}

Data are expressed as mean $\pm \mathrm{SD}$ of the total number of observations. One-way analysis of variance was used to compare the pressure-flow curves obtained under different experimental conditions.

\section{Results}

Anatomic and Angiographic Studies

We observed that the bronchial artery arrived as a single vessel from the descending aorta in all but 1 of the pigs (96\%; Figure 3). Cineangiographic images demonstrated that complete revascularization of the tracheobronchial allograft was achieved with our aortic tube technique (Figure 4). 


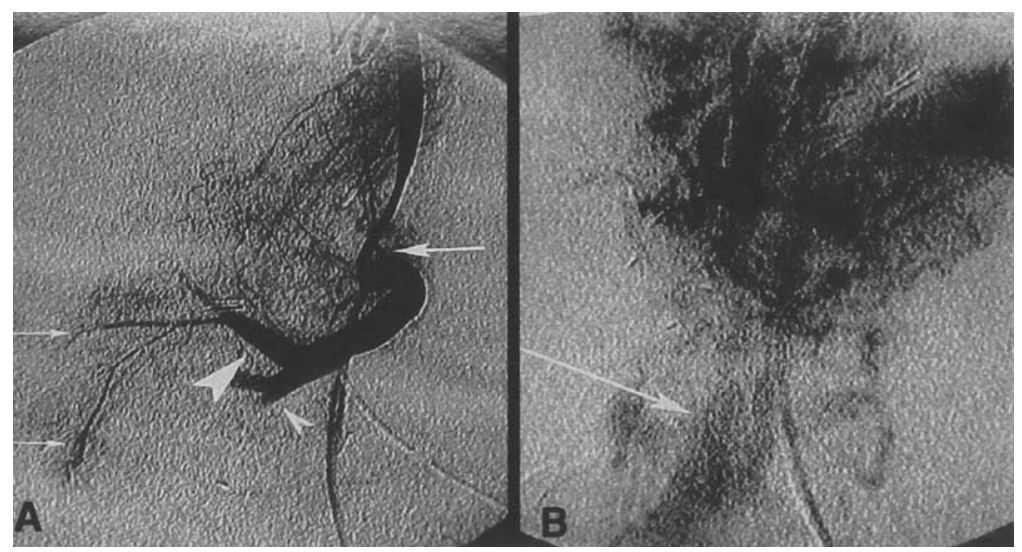

Figure 4. In vivo selective cineangiographic study 8 days after tracheobronchial transplantation in pig 7-998. Allograft was contrasted (Hexabrix; ioxaglate meglumine $39.3 \%$ and ioxaglate sodium $19.6 \%$ injection USP) through retrograde catheterization by right common femoral artery. A, Arterial phase shows patent anastomosis between aortic tube and left carotid artery. Graft revascularization is complete, with exuberant inferior thyroid artery branches (small arrows) and branches originating at bronchial artery (large arrow). Large arrowhead indicates right subclavian artery; small arrowhead shows left subclavian and carotid arteries. B, Venous phase. Opacification of receptor's superior vena cava can be clearly observed (arrow) after bolus injection of $20 \mathrm{~mL}$ contrast medium through aortic tube.

TABLE 1. Histologic evolution and postoperative findings in pigs submitted to tracheobronchial transplantation

\begin{tabular}{|c|c|c|c|c|c|c|}
\hline Pig & Day 2 & Day 7 & Day 14 & Day 21 & Mucus & Postoperative remarks \\
\hline $1-443$ & 0 & 0 & 0 & —* & Present & Killed day 14 with normal graft \\
\hline $2-582$ & 1 & 0 & 0 & 0 & Present & None \\
\hline $3-635$ & 0 & 0 & 0 & 0 & Present & None \\
\hline $4-689$ & 0 & 4 & - $^{*}$ & 一 $^{*}$ & Present on day 4 & $\begin{array}{c}\text { Postangiography thrombosis on } \\
\text { day } 5\end{array}$ \\
\hline $5-626$ & 1 & 0 & 0 & 0 & Present & None \\
\hline $6-729$ & 0 & 0 & 2 & 3 & Decreased on day 17 & $\begin{array}{c}\text { Day } 14 \text { with normal graft, ischemic } \\
\text { necrosis on day } 21\end{array}$ \\
\hline $7-998$ & 0 & 0 & 0 & 0 & Present & None \\
\hline 8-997 & 0 & 0 & 0 & 0 & Present & None \\
\hline $9-428$ & 0 & 4 & 一 $^{*}$ & - $^{*}$ & Absent on day 4 & $\begin{array}{l}\text { Blood transfusion on day } 1, \\
\text { ischemic necrosis, secondary } \\
\text { infection }\end{array}$ \\
\hline $10-523$ & 3 & 一 $^{*}$ & 一 $^{*}$ & 一 $^{*}$ & Absent & $\begin{array}{l}\text { Venous anastomosis angulation, } \dagger \\
\text { ischemic necrosis }\end{array}$ \\
\hline $11-328$ & 1 & 4 & 一 $^{*}$ & 一 $^{*}$ & Absent on day 3 & $\begin{array}{c}\text { Ischemic necrosis, secondary } \\
\text { infection }\end{array}$ \\
\hline
\end{tabular}

Tracheobronchial allografts were assessed according to an arbitrary semiquantitative 0 to 4 scale: 0 , Normal tracheobronchial wall; 1 , isolated lesions of the epithelium; 2, ischemic necrosis with or without hemorrhage of the chorion; 3 , ischemic necrosis of the submucosa; 4 , ischemic necrosis of the cartilage.

*No histologic examination.

tTechnical mishap.

\section{Clinical and Immunologic Findings}

No perioperative mortality was observed among the 11 animals operated on consecutively. Donor and recipient pigs weighed $21.5 \pm 3.2$ and $23.1 \pm 4.3 \mathrm{~kg}$, respectively. The mean times for harvesting and implantation were 97.4 \pm 24.4 and $168.3 \pm 13.1$ minutes, and the mean time of ischemia was $162 \pm 27.3$ minutes. The length of the tracheobronchial graft was $17.2 \pm 0.9 \mathrm{~cm}$. There was agreement between the findings of tracheal, carinal, and bronchial biopsies and macroscopic findings in all cases. Table 1 shows the histologic evolution and most relevant postoperative findings in transplanted animals. 


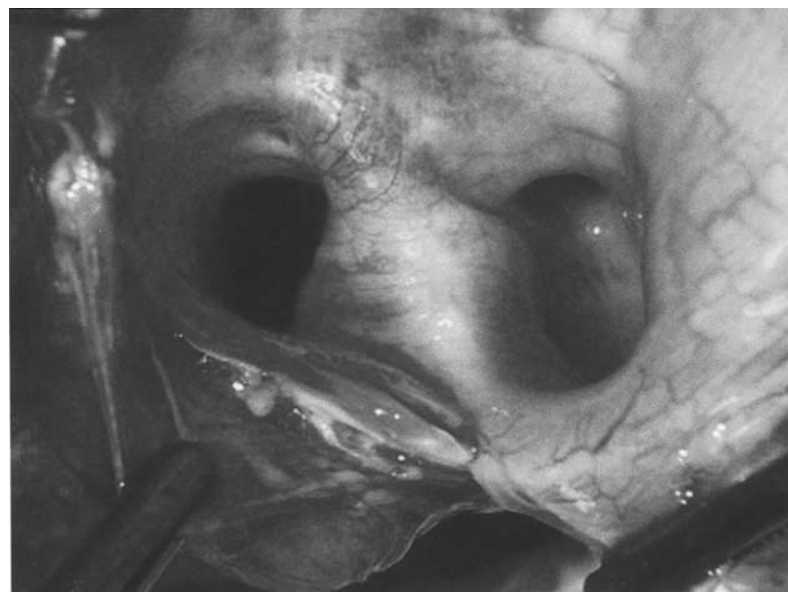

Figure 5. Perioperative exposure of carinal region. Note rich submucosal vascular plexus and hemorrhagic tracheal border.

The tracheobronchial allografts kept in cold ischemia $\left(4^{\circ} \mathrm{C}\right)$ were colorless after perfusion with an organ preservation solution. Immediately after recirculation, exuberant revascularization was observed in all animals, and the mucosa turned pink (Figure 5). The final portion of the trachea and two bronchi showed bleeding on the edges (with thin streams of blood flowing out of small arteries). Figure 6 clearly shows the quality of revascularization in the carinal region.

Seven pigs (64\%) had normally epithelialized mucusproducing allografts with correct morphologic conformation and cartilage viability on day 14 . One pig (1-443) was killed on day 14. Of the 6 remaining animals, 5 recovered normally until the 21st postoperative day, but 1 (6-729) showed a pale and dry graft, clearly contrasting with previous macroscopic findings. This pig demonstrated a gradual decrease in $\mathrm{CD}^{+} \mathrm{T}$ cell levels concomitant with an increase in $\mathrm{CD}^{-} \mathrm{B}$ cells on day 21 , characteristic of late rejection.

Four animals (36\%) had early severe necrosis develop as a result of arterial thrombosis after intense angiographic manipulation ( 1 case), venous axis angulation resulting from a technical mishap (1 case), and acute rejection (2 cases, pigs 9-428 and 11-328). This acute graft rejection was evidenced by an increased $\mathrm{CD} 4^{+} / \mathrm{CD}^{+}$ratio (Figure 6 ), and the pigs were killed on day 7 with necrotic allografts. The first animal showed a sudden rise in $\mathrm{CD} 4^{+} \mathrm{CD} 8^{-}$ level (205 cells $/ \mathrm{mm}^{3}$ on day 0,1399 cells $/ \mathrm{mm}^{3}$ on day 3$)$; in the second animal, the most important finding was a progressive increase in the $\mathrm{CD} 3^{+} \mathrm{CD} 4^{-} \mathrm{CD} 8^{-}$cytotoxic subset ( $\gamma \delta$ cells) level ( 402 cells $/ \mathrm{mm}^{3}$ on day 0,1557 cells $/ \mathrm{mm}^{3}$ on day 3,1772 cells $/ \mathrm{mm}^{3}$ on day 7).

A decrease or value below 0.6 in the $\mathrm{CD} 4^{+} / \mathrm{CD} 8^{+}$ratio was consistently observed in all animals featuring healthy allografts on histologic examination (Figure 6).

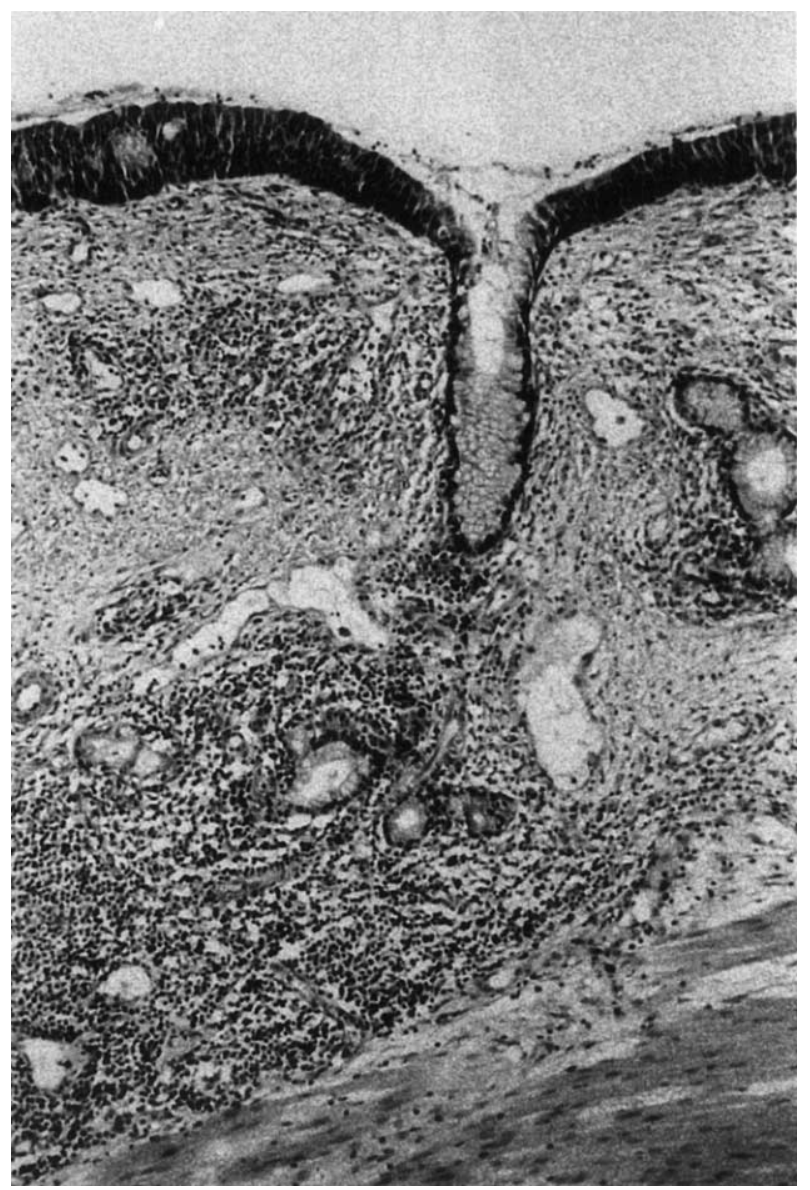

Figure 6. Histologic appearance of tracheobronchial graft (pig 8-997) on day 21, with well-differentiated epithelium (top) and mononuclear infiltrate around submucosal glands and vessels (lower left corner).

\section{Flow Cytometric Phenotype Study}

Of the 11 animals 6 , among which were the 2 cases of acute rejection, were submitted to flow cytometric analysis. Figure 7 shows the findings concerning $\mathrm{CD} 4^{+} / \mathrm{CD} 8^{+}$ratio.

\section{Ex Vivo Pressure-Flow Relationship in Isolated Tracheobronchial Grafts}

Perfusion by both the subclavian artery and the aortic tube demonstrated lower vascular resistance in the territory supplied by the bronchial artery than in the territory supplied by the inferior thyroid artery $(P<.12$, not significant). Resistance was significantly different in the graft as a whole from the bronchial artery territory $(P<.013)$ and the inferior thyroid artery territory $(P<.005)$. Ex vivo tracheobronchial allografts showed reproducible pressure-flow curves (Figure $8)$.

\section{Discussion}

As a development of our previous studies, and to ensure the viability of the entire trachea, carinal region, and stem 


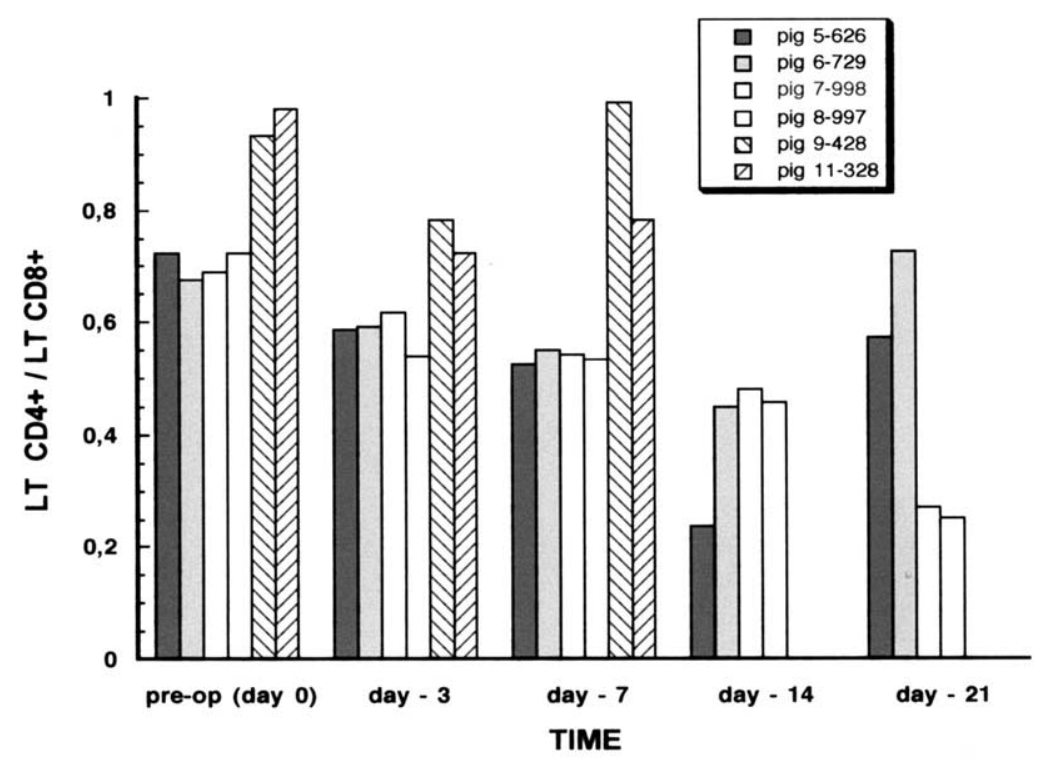

Figure 7. $\mathrm{CD4}^{+} / \mathrm{CD8}^{+}$ratio in peripheral blood in 6 pigs as determined by pig-specific monoclonal antibodies. Ratio below 0.60 is observed in pigs with good immunosuppression. $C D 4^{+}$, Helper T cells; $C D 8^{+}$, cytotoxic T cells.

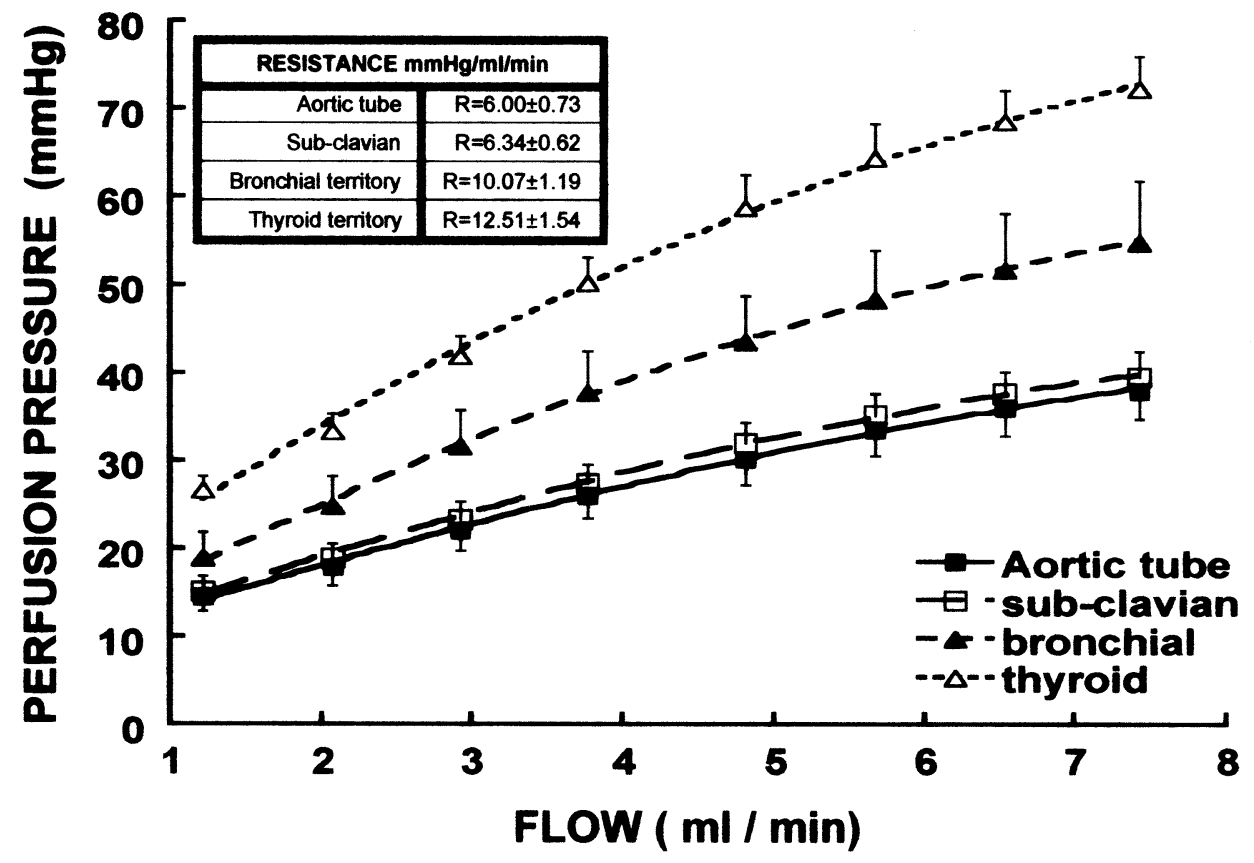

Figure 8. Pressure-flow linear curves and vascular resistance in ex vivo tracheobronchial allografts. Following comparisons were made: 1 vs $3, P<.013 ; 2$ vs $4, P<.005 ; 3$ vs $4, P<.12$.

bronchi, we created a new technique of dual blood supply that aligned in the same vascular axis the bronchial artery and the inferior thyroid artery (Figure 1), enabling complete tracheobronchial revascularization. In human beings, the inferior thyroid artery has been shown to be sufficient to revascularize on average $6.5 \pm 1.1 \mathrm{~cm}$ of the superior tracheal tissue. ${ }^{16}$ Also, with the use of the right inferior thyroid artery, we have already shown the feasibility of transplanting the cervical and uppermost intrathoracic trachea $(9.75 \pm 1.5 \mathrm{~cm})$ in the pig. ${ }^{12}$

The number of bronchial arteries varies among species and individuals. ${ }^{17}$ In human beings, three or more bronchial 
arteries have been observed in $90 \%$ of cases. ${ }^{18}$ It has long been known that bronchial artery revascularization is the best way ensure good healing of tracheal and bronchial anastomoses after lung transplantation. ${ }^{19,20}$ An aortic patch including the bronchial artery was implanted by Mills and coworkers ${ }^{20}$ in the aortas of recipient dogs during left lung transplantation. They observed bronchial anastomotic necrosis and dehiscence in cases of bronchial artery occlusion. We made similar observations after postangiography aortic tube thrombosis in 1 pig. Laks and colleagues ${ }^{21}$ have already demonstrated the efficacy of an aortic segment encompassing the bronchial arteries to heal airway anastomoses in a primate model.

Our main challenge in this study was to construct a bronchial artery pedicle coupled with the inferior thyroid artery axis. Current bronchial artery revascularization techniques in lung and heart-lung transplantation include saphenous vein ${ }^{22}$ or internal thoracic artery ${ }^{23}$ bypass anastomoses with the origins of the bronchial arteries located in the aortic patch. In addition, sequential anastomoses are stimulated to achieve complete bronchial artery revascularization. ${ }^{24}$ Meanwhile, surgical expertise in lung transplantation without bronchial artery revascularization has been directed toward shortening of donor bronchus, because it appears less vulnerable to the absence of systemic blood supply than are the trachea and proximal main bronchi. ${ }^{25}$

The heterotopic model is remarkable because it allows daily inspection and cleaning of mucus, as well as the performance of bronchoscopic biopsies without respiratory distress. Our work confirmed that mucus production depends on good vascularization. ${ }^{26}$

The advantages of cryopreservation relative to pharmacologic immune modulation to prevent an allogeneic response have recently been challenged. ${ }^{27}$ However, it is true that cryopreserved allografts wrapped in omentum present weak activation of host lymphocytes. ${ }^{28}$ Differently, in our tracheobronchial allograft, a large surface area of antigenic donor epithelium and mixed glandular tissue (both expressing HLA class II subregion genes ${ }^{29}$ ) interacted immediately with the recipient's blood after recirculation. Thus failure of immune suppression led to subepithelial thickness, mononuclear vasculitis, and thrombosis.

Ex vivo tracheobronchial allografts had never before been studied. We showed that resistance was lower in the bronchial vascular bed than in the inferior thyroid vascular bed. This could be related to the bronchopulmonary connections. Graft recirculation allowed us to observe bleeding from portions of the pulmonary veins, indicating anastomosis between the bronchial and pulmonary circulations, as already reported in human beings. ${ }^{30}$ Vasa vasorum of the pulmonary artery connecting to bronchial artery branches has been observed in pigs. ${ }^{31}$ Our experiment corroborates these findings.
Circumferential resection with primary tension-free anastomosis is not possible in stenotic lesions longer than 6 $\mathrm{cm}$. Additionally, recurrence causes tissue fixation and turns a second failure into an extremely delicate situation in which the outcome may be a permanent tracheostomy. ${ }^{32}$ Patients with an existing mediastinal tracheostomy may also be rehabilitated by coupling laryngeal transplantation ${ }^{3}$ with subtotal (based on the inferior thyroid artery) or complete (aortic tube technique) main airway transplantation. This study describes an experimental model of tracheobronchial revascularization, not a clinically relevant tracheal transplantation technique.

In short, bronchial artery supply was a sine qua non to ensure the viability of the inferior trachea, carina, and stem bronchi. As demonstrated, our original dual blood supply technique provided sufficient blood supply to these areas.

We thank all persons who work in the CCML Surgical Laboratory, especially Benoît Decante, Nadia Sedjoro, Maîte Ghienne, Frederic Seccatore, Hégésipe Langouste, and Bruno Baudet, for their technical contributions.

\section{References}

1. Backer CL, Mavroudis C, Gerber ME, Holinger LD. Tracheal surgery in children: an 18-year review of four techniques. Eur J Cardiothorac Surg. 2001;19:777-84.

2. Van Veenendaal MB, Liem KD, Marres HA. Congenital absence of the trachea. Eur J Pediatr. 2000;159:8-13.

3. Birchall M. Human laryngeal allograft: shift of emphasis in transplantation. Lancet. 1998;351:539-40.

4. Macchiarini P. Tracheal transplantation: beyond the replacement of a simple conduit. Eur J Cardiothorac Surg. 1998;14:621-3.

5. Moriyama H, Sasajima T, Hirata S, Yamazaki K, Yatsuyanagi E, Kubo Y. Revascularization of canine cryopreserved tracheal allografts. Ann Thorac Surg. 2000;69:1701-6.

6. Martinod E, Zegdi R, Zakine G, Aupecle B, Fornes P, D'audiffret A, et al. A novel approach to tracheal replacement: the use of an aortic graft. J Thorac Cardiovasc Surg. 2001;122:197-8.

7. Vacanti CA, Paige KT, Kim WS, Sakata J, Upton J, Vacanti JP. Experimental tracheal replacement using tissue-engineered cartilage. J Pediatr Surg. 1994;29:201-5.

8. Nakanishi R, Shirakusa T, Takachi T. Omentopexy for tracheal autografts. Ann Thorac Surg. 1994;57:841-5.

9. Baile EM, Jasso-Victoria R, Sotres-Vega A, Selman-Lama M, Villalba J, Arreola JL, et al. Tracheobronchial blood flow after a modified canine lung autotransplant: effect of omental wrapping. Transplant Proc. 1992;24:2024-9.

10. Mukaida T, Shimizu N, Aoe M, Andou A, Date H, Moriyama S. Origin of regenerated epithelium in cryopreserved tracheal allotransplantation. Ann Thorac Surg. 1998;66:205-8.

11. Neville WE, Bolanowski PJP, Soltanzadeh H. Homograft replacement of the trachea using immunosuppression. J Thorac Cardiovasc Surg. 1976;72:596-601.

12. Macchiarini P, Lenot B, de Montpreville V, Dulmet E, Mazmanian GM, Fattal M, et al. Heterotopic pig model for direct revascularization and venous drainage of tracheal allografts. J Thorac Cardiovasc Surg. 1994;108:1066-75.

13. Salassa JR, Pearson BW, Payne WS. Gross and microscopical blood supply of the trachea. Ann Thorac Surg. 1977;24:100-7.

14. Patterson GA, Todd TR, Cooper JD, Pearson FG, Winton TL, Maurer J. Airway complications after double lung transplantation. J Thorac Cardiovasc Surg. 1990;99:14-20.

15. Gade J, Norgaard MA, Andersen CB, Pettersson G, Svendsen U, Olsen 
P. The porcine bronchial artery: surgical and angiographic anatomy. $J$ Anat. 1999;194:241-7.

16. Salmeron J, Gannon PJ, Blackwell KE, Shaari CM, Urken ML. Tracheal transplantation: superior and inferior thyroid artery perfusion territory. Laryngoscope. 1998;108:849-53.

17. Deffebach ME, Charan NB, Lakshminarayan S, Butler J. The bronchial circulation. Small, but a vital attribute of the lung. Am Rev Respir Dis. 1987;135:463-81.

18. Schreinemakers HH, Weder W, Miyoshi S, Harper BD, Shimokawa S, Egan TM, et al. Direct revascularization of bronchial arteries for lung transplantation: an anatomical study. Ann Thorac Surg. 1990;49:4454.

19. Metras H. Note preliminaire sur la greffe totale du poumon chez le chien. Proc Acad Sci. 1950;231:1176-7.

20. Mills NL, Boyd AD, Gheranpong C. The significance of bronchial circulation in lung transplantation. J Thorac Cardiovasc Surg. 1970; 60:866-74

21. Laks H, Louie HW, Haas GS, Drinkwater DC, Lewis W, Permut LC, et al. New technique of vascularization of the trachea and bronchus for lung transplantation. J Heart Lung Transplant. 1991;10:280-7.

22. Couraud L, Baudet E, Martigne C, Roques X, Velly JF, Laborde N, et al. Bronchial revascularization in double-lung transplantation: a series of 8 patients. Ann Thorac Surg. 1992;53:88-94.

23. Daly RC, Tadjkarimi S, Khaghani A, Banner NR, Yacoub MH. Successful double-lung transplantation with direct bronchial artery revascularization. Ann Thorac Surg. 1993;56:885-92.

24. Norgaard MA, Efsen F, Andersen CB, Svendsen UG, Pettersson G. Medium-term patency and anatomic changes after direct bronchial artery revascularization in lung and heart-lung transplantation with the internal thoracic artery conduit. J Thorac Cardiovasc Surg. 1997;114: 326-31.

25. Norgaard MA, Olsen PS, Svendsen UG, Pettersson G. Revascularization of the bronchial arteries in lung transplantation: an overview. Ann Thorac Surg. 1996;62:1215-21.

26. Marelli D, Paul A, Nguyen DM, Shennib H, King M, Wang NS, et al. The reversibility of impaired mucociliary function after lung transplantation. J Thorac Cardiovasc Surg. 1991;102:908-12.

27. Nakanishi R, Hashimoto M, Muranaka H, Yasumoto K. Effect of cryopreservation period on rat tracheal allografts. $J$ Heart Lung Transplant. 2001;20:1010-5.

28. Liu Y, Nakamura T, Shimizu Y, Ueda H, Yoshitani M, Toba T, et al. Tracheal allotransplantation in beagle dogs without immunosuppressants. Ann Thorac Surg. 2001;72:1190-4.

29. Bujia J, Wilmes E, Hammer C, Kastenbauer E. Tracheal transplantation: demonstration of HLA class II subregion gene products on human trachea. Acta Otolaryngol. 1990;110:149-54.

30. Tobin CE. The bronchial arteries and their connections with other vessels in the human lung. Surg Gynecol Obstet. 1952;95:741-50.

31. Fadel E, Mazmanian GM, Chapelier A, Baudet B, Detruit H, de Montpreville V, et al. Lung reperfusion injury after chronic or acute unilateral pulmonary artery occlusion. Am J Respir Crit Care Med. 1998;157:1294-300.

32. Donahue DM, Grillo HC, Wain J, Wright CD, Mathisen DJ. Reoperative tracheal resection and reconstruction for unsuccessful repair of postintubation stenosis. J Thorac Cardiovasc Surg. 1997;114:934-9.

\section{Online-www.aats.org}

Now you can get The Journal of Thoracic and Cardiovascular Surgery online. The Journal online brings you faster delivery time, easy searching of current and back issues, links to PubMed, AATS, WTSA, and other important sites, and more. Visit the Journal online today.

\section{Receive tables of contents by e-mail}

To receive the tables of contents by e-mail, sign up through our Web site at http://www.mosby.com/jtcvs

Choose E-mail Notification

Simply type your e-mail address in the box and click the Subscribe button. Alternatively, you may send an e-mail message to majordomo@mosby.com. Leave the subject line blank and type the following as the body of your message: subscribe jtcvs_toc

You will receive an e-mail to confirm that you have been added to the mailing list.

Note that TOC e-mails will be sent out when a new issue is posted to the Web site. 